\title{
JOHN THE BAPTIST APPROACH TO CORRUPTION: A RECIPE FOR THE CHURCH IN AFRICA
}

\author{
UDC 343.352:277.4](662.6)
}

\begin{abstract}
Abiodun Simeon Ige
Kogi State University, Anyigba, Nigeria

Abstract. This article discuses how to curb the menace of corruption in Africa. It employs a biblical account of how John the Baptist fearlessly confronted corrupt cases headlong during his days. Typologically, it is observed that in pristine Africa, Africans cherished values like honesty, love for neighbours, community spirit and other values distinct from those that are prominent today (individualism, selfishness, bribery, embezzlement, hoarding of wealth, dishonesty). The article establishes the fact of the high rate of corruption in Nigeria and in Africa in general today, to the point that corruption has almost become part of the African culture. The aim of the article is to carefully examine the menace of corruption in Africa and to suggest John the Baptist's approach as a recipe for the church so as to curb the devastating effect of corruption in Nigeria and on the African continent.
\end{abstract}

Key words: Africa, corruption, Church, development, Nigeria, values

\section{INTRODUCTION}

The high rate and destructive influence of corruption may have been the bane of economic growth and development in Africa. Corruption, which has almost become part of African culture, is one of the many major social vices that have been ravaging the African society. While commenting on the rate of corruption in Nigeria, Chinua Achebe says:

My frank and honest opinion is that anybody who can say that corruption in Nigeria has not yet become alarming is either a fool, a crook or else does not live in this country ... Corruption in Nigeria has passed the alarming and entered the fatal stage (Achebe, 1983: 46-47).

Corrupt persons today are so systemic in style and have employed sophisticated tactics. In Nigeria, for instance, ethnicity and favouritism (tribal, religious, denominational, and so

Received September $10^{\text {th }}, 2016 /$ Accepted December $23^{\text {rd }}, 2016$

Corresponding author: Abiodun Simeon Ige

Department of Religious Studies, Faculty of Art and Humanities, Kogi State University, P.M.B.1008, Anyigba Kogi State, Nigeria

E-mail: abiodunige68@gmail.com 
on) is the order of the day. If the situation involves a bureaucracy, those capable of saying no to the bribe on the bureaucratic chain are easily getting caught in the web. Where the crime becomes an open secret, the case is adjourned several times until it is forgotten or hung up the line; probably those in the position to prosecute the crime get caught-up in the web, advised or instructed by some high rank members of the neo-patrimonial networks to hands off the matter. Anyone within the bureaucracy who objects may be coerced by an offer a person cannot resist, or deny the person's rights (such as promotion, entitlements, and so on), or by direct threat to life and even removal from office among others ${ }^{1}$. A former minister of the Federal Republic of Nigeria, Chief Don Etiebet, rightly says:

No task force put in place can check them because, virtually everyone from the government, police, customs, have been imbibed into the smuggling racket ${ }^{2}$.

The rate of corruption is so high that the Federal House of Representative in Nigeria is now contemplating hanging for treasury looters ${ }^{3}$ as a solution to corruption.

Today, the effect of corruption cuts across the various strata of the society: economic, education, political, social and, even, religious. The challenge of this article is the high rate and effect of corruption in Africa that seems to have defiled solution. What then is the solution to this ravaging wolf, called corruption, devouring the Africa continent? In that context, this article seeks to investigate John the Baptist's concept of combating corruption in his days as a recipe to fight the menace of corruption in contemporary Africa and Nigeria in particular. This article uses the socio-historical and typological methods of research to drive home the salient Biblical principles as adopted by John the Baptist as a solution to the web of corruption that has retarded the growth of Africa.

\section{LITERATURE REVIEW}

\subsection{Socio-political context of John the Baptist's message}

According to the Lucan narrative, John started prophetic ministry in the fifteenth year of the reign of Tiberius Caesar. This was when Pontius Pilate was governor of Judea, Herod Tetrarch of Galilee, his brother Philip Tetrarch of Iturea and Traconitis, and Lysanias Tetrarch of Abilene (Luke 3:1). This was also during the high priesthood of Annas and Caiaphas. This record supports Drane's assertion that the world of the first Christians, the outward forms of administration and government were those of the Roman Empire, but its cultural roots were embedded in a different world altogether (Drane, 2012: 294).

The political setting before and during the time of John the Baptist was GraecoRoman because the Lucan narrative says the birth of John was foretold in the time of Herod King of Judea (Lk1:5). However, John's life and ministry came totally under the Roman domination of Judea, his native home. After the death of Herod the Great, his kingdom was divided among his three sons: Archelaus, Herod Antipas and Herod Philip.

\footnotetext{
${ }^{1}$ This opinion is advanced by Igwe, Stanley C. in his book titled: How Africa Underdeveloped Africa, Professional Printers \& Publishers: Port Harcourt Nigeria, 2010, p.99.

${ }^{2}$ This view was advanced by Chief Don Etiebet, A Former Nigeria Federal Minister for Petroleum. For detailed information on his view, see Sunday Tribune 26, Sept. 1993: "Oil Smuggling: Government officials indicted." (pp. 1\&4).

${ }^{3}$ This view was recently echoed by Honourable Umar Yakubu Barde, The Minority Whip of the House of Representative. For detailed information on his view, see Sunday Tribune 24, January 2016: "Reps may consider hanging, amputation for treasury looters" (pp. 1\& 4).
} 
Augustus Caeser divided the kingdom to Herod's three sons. Roetzel says half the kingdom (Judea, Idumea and Samana) went to Archelaus who took the title ethnarch (ruler of a people). The other half was divided into two tetrarchies, one to Philip and the other to Antipas. Galilee and Peraea were assigned to Herod Antipas (4BCE-39CE), while the northeastern parts of Jordan (Batanaea, Trachonitis, Auranitis and Territory around Paneas in northern Galilee) were given to Philip (4BCE - 34CE) (Roetzel, 1985:16). Stambaugh and Balch write that both Antipas and Philip were given the title tetrarch "leader of a fourth" (Stambaugh, Balch, 1986: 25).

Herod Antipas (the son of Malthace - a Samaritan- and Herod the Great simply referred to in the gospels as Herod) attracts our attention. Jesus of Nazareth and John the Baptist had special encounters with him. He was responsible for the imprisonment and execution of John, who had made a public issue over Antipas' marriage to Herodias, a marriage that violated two Jewish laws (Matt. 14:1 - 11, Luke 3:19 - 20). The gospel of Mark gives insight to situations in Antipas court, peopled by courtiers, military officers, leading men, a conniving queen, and even a royal dancing lady (Salome, Herodias daughter and former wife of Philip tetrarch) (Mark 6:21 - 22). Herod Antipas thought of Jesus as John the Baptist whom he beheaded (Luke 9:7 - 9, Matt. 14:1, Mark 6:14 - 16). Jesus equally appeared before him during his various trials (Luke 23:6 - 12). Due to complaints by his relatives in 39CE, Herod was banished to southern France and his territories were given to Agrippa 1(McCain, 1996:14).

Archelaus, son of Herod and Malthace, was the most unfavoured of the three successor of Herod (Matt 2:22) because he encountered political opposition from the beginning of his reign. He was as ruthless as his father (Matt 2:19-23). He was reported to have killed 3000 people during the Passover shortly after he had been promoted to the throne. McCain observes that, because of his ruthlessness, a group of Samaritans and Jewish leaders complained to Rome about his administration. This resulted in him being exiled to Gaul (France) in about 6CE (McCain, 1996:14; Stambaugh, Balch,1986: 25).

Philip the Tetrarch (4BC - CE34) was the son of Herod and Cleopatra. He is mentioned only once in the New Testament where it is said that he was the tetrarch of Iturea and Trachonitis when John the Baptist began his ministry (Luke 3:1). Jesus visited his areas many times. Philip had rebuilt a city and renamed it Caesarea Philippi. This was where Peter's great confession took place (Matt. 16: 13 -20). He was a reasonable fair and well-liked ruler unlike most of his relatives.

In the socio-economic milieu, there was economic inequality in the early Roman Empire. Financial resources were probably the single and most influential factor in determining one's place in the social economy, but this is not the only factor. Others would have included gender, family lineage, ethnicity, legal status (slave, freed or freeborn), occupation and education (Friesen, 2008: 20). There are three things that we must bear in mind. First, the Roman imperial economy was said to be pre-industrial. Second, there was no middle class in the Roman Empire because the economy was primarily agricultural with wealth based on the ownership of land and most land was controlled by a small number of the wealthy elite families. Third, poverty was widespread both in rural and urban areas (Friesen, 2008: 19).

Indeed, Rome maintained a stratified society as a means of managing the masses. To maintain their elaborate administrative machinery, different taxes were imposed on all subjects, while Roman citizens were exempted. Taxes were levied on the produce of the land, on men, property, sale of animals and all transport of goods across borders including "head tax" which was mandatory on every person. In some provinces, the head tax applied 
only to males but in Syria, to which Judea belonged, everybody paid tax. Tax eligibility was between the ages of twelve or fourteen and sixty five, and it was a flat rate (Stambaugh, Balch, 1986: 78). Adding to the administrative burden of taxation was the priestly imposed taxes. Jewish males paid half-shekel for support at the Temple and tithes were also demanded by religious law to be paid to the priests and Levites (Draper, 1992: 51-73). The presence of Roman soldiers who served as middlemen equally compounded the problem (Luke 3:14, 7:1-10). Invariably, the people were over-taxed. Bruce observes that the rich became richer as a result of their own covetousness or greed, or that of their ancestors. Significantly, the rich were presumed to have become rich by depriving others, defrauding and eliminating others, prospering by having others become wretched, pitiable, ill, and blue and naked (Bruce, 1979: 357). The rich had guards that would force their will by maiming and killing the poor (like they beheaded John the Baptist) (Matt. 21:33-46; Act 21:30-32). The poor small scale farmers out of desperation sometimes turned to robbery for survival.

\subsection{The Man John the Baptist and his message}

John the Baptist was known as a prophet and a Jewish itinerant preacher in the early first century CE, and is revered as a major religious figure in Christianity, Islam, the Bahai and Mandaeism. He is known as Prophet Yahya in the Qur'an. John was born on March $25^{\text {th }}, 7 \mathrm{BC}$ in Jerusalem in accordance with the promise that Angel Gabriel made to Elizabeth and Zachariah in June of the previous year ${ }^{4}$. John's grandparents were Bianca and Zachariah.

John was taken to Engedi near the Dead Sea by his parents where he was duly and solemnly inducted into the Nazarite brotherhood order for life. At the ceremonies, John made the vows to abstain from all intoxicating drinks, to let his hair grow and to refrain from touching the dead. Thereafter, the family proceeded to Jerusalem where he completed the offerings which were required of those taking Nazarite vows before the temple. He had an unusual flair for fashion; his clothes had a leather belt round his waist. His food was locusts and wild honey (Matt 3:4)

The narrative of the beginning of John's ministry in the New Testament says it was shortly before the commencement of the ministry of Jesus Christ (Matt 3:1-12; Luke 3:2-14). He breaks the prophetic silence which had characterized the so-called "four hundred silent years". He preaches in the wilderness of Judea (Matt. 3:1) and at Aenon near Salim (John 3:23). Many people went out to hear John from Jerusalem, and all Judea and the whole region of the Jordan confessing their sins and were baptized by him in the Jordan River (Matt. 3:5-6). John preaches a message of repentance and he is described as "The voice of one crying in the wilderness: Prepare the way of the Lord, make his paths straight" (Matt. 3:3) in fulfillment of Isaiah's prophecy in Isaiah 40:3.

John's effort at combating corruption in his days was a call to a change of heart and return to God. He challenges people to quit sinning and seek righteousness. He was disgusted with the priesthood and the political leaders and the level of corruption that engulf Temple and the society. His message startled his countrymen especially the note of urgency he added to his preaching "for the Kingdom of heaven is at hand" (Matt. 3:2). John's message contains ethical instructions, prophetic denunciation of the status quo, like the Old Testament Prophets such as Amos 4:1 - 3; Micah 3:5 - 7, and eschatological teaching. He was fearless, stern and his preaching full of fire and faithfulness. This suggests why Bruner describes him as "rough,

${ }^{4}$ The Urantia Book, Paper 135: John the Baptist; http://www.urantia.org/urantia-book-standardized/paper-135john-baptist, Assessed 10-2-2016 
crude, fundamentalist and a little fanatical'(Brunner, 1987: 72). But, with this attitude of combating corruption through his stern, frank messages, he got results. This could be seen from the persons who went and were baptized by him as a sign of attitudinal change. John's baptism was a sign of a greater Baptism of the Holy Spirit and fire with which the messiah would baptize the people (Matt. 3:11).

The direct, radical dimension and renewed note of urgency John utilized in confronting and condemning the Pharisees and Sadducees is noteworthy. The Pharisees are by far the most influential sect among the Jews of the first century. They had definite membership with emphasis on conformity to the law as expressed in the Old Testament and the oral law. The Sadducees are the supporters of the Hasmonean priest-King and a smaller group than the Pharisees, but they wielded more political influence because they controlled the priesthood. John, courageous as he was, called them "you brood of vipers" and charged them to produce fruit that befits repentance (Matt. 3:7-8; Luke 3:7 - 8). This is a kind of metaphor to depict the evil and wicked nature of these two sects, except there is an inner transformation. The attack on them gave a time warning; the time is short in the statement "the axe is laid to the root of the trees..." (Matt. 3:10; Luke 3:9). Thus, any waste of time to repent may be too late. The thought of the Jews (Pharisees and Sadducees) of their privileged position as sons of Abraham, and therefore members of God's chosen people, is a fallacy. John charges them that if they wish to escape the coming judgment, repentance must be evidenced by a change in their character. This true spirituality as a "fruit" in this context is against the Jewish view of acts of charity, mercy and show of justice (Hosea 6:6; Acts 26:20).

Luke's Gospel narrative adds an interesting passage that is not found in Mathew and Mark. Luke reports that John gave practical suggestions for the implementation of genuine repentance in response to the crowd's question. John recommends that he who has two tunics (clothing) and food should share with the less privileged (Luke 3:11). Tax collectors were also instructed not to be greedy but to "collect no more than is appointed you" (Luke $3: 12$ - 13). The soldiers were equally charged not to be extortionists, not to accuse people falsely but to be content with their wages (Luke 3:14). Laurence remarks that the swaggering and bullying soldiers were told to refrain from summary appropriation of the goods of others and from glib perjury to cover their tracks. ${ }^{5}$ This direct and practical approach actually added weight to John's message.

John's prophetic ministry and attack on corruption actually reached its climax when he courageously confronted King Herod Antipas. John rebuked him of adultery for marrying Herodias, the wife of his brother Philip, and all the other evil things he had done (Luke 3:19; Matt. 14:4; Mark 6:18). King Herod feared John and protected him knowing him to be a righteous and holy man (Mark 6:20) Nevertheless, he ordered his arrest and imprisonment. But Herodias (whom he forcefully took from Philip) sought for an opportunity to kill John and the opportunity came on King Herod's Birthday. Amidst fun fare, dancing, music, feasting and intrigue, John was beheaded and his head brought on a platter at the order of King Herod Antipas (Mark 6:27 - 28). John died at Machaerus and was buried by his disciples (Matt. 14:11-12; Mark 6:29).

It is significant to note that John, despite his doggedness against the evils in the society, still demonstrated an unusual humility worthy of emulation. He did not blow his own

\footnotetext{
${ }^{5}$ Laurence E. Porter, 'Luke', in: Bruce F.F., New International Bible Commentary, based on the NIV, Michigan: Zondervan Publishing House, 1979. pp. 1182 - 1228.
} 
trumpet, but that of Jesus Christ - the expected messiah. John says of Jesus "I baptize you with water for repentance, but he who is coming after me is mightier than I, whose sandals I am not worthy to carry; he will baptize you with the Holy Spirit and with fire" (Luke 3:16; Matt. 3:11; Mark 1:7). Instead of being filled with jealousy and envy, he rejoiced at the large crowd that followed Jesus and never tried to usurp Jesus or arrogate certain authority to himself.

It also is pertinent to note that despite John's doggedness at eradicating corruption, there is no recommendation for violence, riot or overthrow of existing government leaders, but an insistence on moral principles in the life of the leaders so that the society may be transformed.

\subsection{Neglected Core African values}

The pristine Africa society is one to be cherished. Africans did not live lives of individualism, capitalism and oppression. Africa harboured no criminals, thieves, kidnapers and the likes. In the so-called primitive Africa community, traders left their product for sale by the roadside till the following morning without fear of losing them. Whoever wanted to buy understood the price of the commodity by signs placed close to the commodity. He or she then dropped the money on the ground and no one touched it until the owner came around.

In traditional Nigeria society, for example, people placed premium on integrity. This was when Nigeria still existed as a heterogeneous community. Among the Yoruba, for instance, value is placed on morality, child upbringing and integrity among others. Family names were held in high esteem. People abstained from involvement in any vices, such as: corruption, stealing, embezzlement and the likes, in order to preserve the integrity of the family name. Africans in general, and the Yoruba in particular, do not believe in the concept of individualism. Mbiti observes that the child's upbringing belongs to the corporate body of kinsmen even if the child bears the name of the father (Mbiti, 1970: 128-139). A child is expected to be of good character, to respect elders, to be loyal to ones parents, to be honest in all public and private dealings, to show devotion to duty and others (Anyanwu, 2010: 156). These cores African value systems helped to prevent corruption, selfishness and other vices hampering the growth of the nation and the African continent today.

It is important to note that in the Yoruba culture and religion, it is mandatory to take care of the poor and destitute. It is even a requirement for favour from Olodumare for good life. The Yoruba take care of even strangers, not necessarily poor, out of the belief that such persons could be the spirit of ancestors or angels wandering around. It is not that the poor did not exist, but the fact is that the poverty was shared by all. The community bore the burden together. The 'haves' share with the 'have not's.' The traditional Yoruba (Africa) community is altruistic. It is in this spirit of caring for one another that one appreciates the Yoruba communal living. This is similar to the communal life of the early Church which was a community that had the thought of the good of all (Ige, 2009:108).

Unfortunately, in Africa's society today, these cultural values and practices are fast becoming a thing of the past. What could be the reason for this? It is most likely due to a change from Africa's heterogeneous kingship system to a new enlarged system of administration, as well as the new discoveries in the natural resources meant to improve the economic life and civilization, now instilled in Africans grid and desire to acquire wealth. Individualism, capitalism, selfishness, corruption, embezzlement, bribery, hoarding of wealth (money laundering), non-payment of workers' wages as an outcome of dishonesty 
from the leaders (and so on) are now taking over our good, happy, peaceful and so-called primitive communalism. The question is: can these core values be restored in the contemporary church in Africa and in the Africans in general?

\subsection{Corruption and the Church today in Africa}

John the Baptist came as a forerunner to Jesus Christ, who is the initiator of the Christian Church. Although Jesus was not a teacher of political economy, he advocated for a new social order. Jesus interactions with the rich ruler (Luke 18:18 - 20) and Zacchaeus the tax collector (Luke 19:1 - 10), among others, show his zero tolerance for corruption. The Church can be seen as an offshoot of the pioneering efforts of both John the Baptist and especially Jesus Christ. The Church is expected to build on the foundation and legacy laid down by them, by championing the anti-corruption crusade.

Looking around us and evaluating the attitude of the Church to corrupt practices in Africa today, it is like the Church has relinquished her exalted spiritual position to embrace the materialistic stand of the society in which she found herself. The Church now appears to be in the world and in love with the world against the scripture. The book of I John 2:15 say: "Do not love the world or the things in the world. If anyone loves the world, love for the father is not in him". The materialistic concept of the ordinary society has been transferred into the Church economic ethics.

As a result of the acquired normative values in the society, those in places of authority in the Church in Africa do not feel responsible for the unfortunate conditions of their followers. Some Church leaders have been seriously infected with the corruption virus. Prosperity preachers today preach that to prosper is to be in a state of abundance, to be in mighty finances where one continues to have more and more. They claim that the real evidence of the blessing of God depends on the amount of material a person possesses.

The commercialization of the gospel has overtaken salvation messages. These "cash and carry pastors", "freelance preachers", "pastors for hire", "emergency pastors", "hungry pastors" (and so on) have given the Church a bad name. They live flamboyant lifestyles like the politicians. They own and maintain private jets ably financed by their Church members who are government workers, peasants and artisans among others.

Money bags and favouritism have taken over the Church. Donors of huge amount of money irrespective of the source(s) are being applauded in the Church and given special seats. Small donors are not recognized; they are being alienated and marginalized. This is another form of corruption similar to terrorism operating in the Church.

In certain societies today, the Church tends to keep silent while corruption thrives like the harmattan wild-fire. Church leaders and founders wine and dine with looters of the nation's treasury and celebrate them in their Churches. Church leaders are not courageous enough to correct corrupt individuals in the society but they shamelessly share in the loots. Unlike the Old Testament Prophets, like Amos and the courageous and fearless New Testament Prophets: John the Baptist and Jesus Christ, Church leaders are possibly afraid of arrest, imprisonment or even death in the name of preaching the gospel. They want to enjoy the reward of their stewardship here on earth and not in heaven. The current situation in Nigeria and Africa in general resembles the proverbial expression: if you cannot correct them, join them. 


\subsection{The noble path}

John the Baptist's effort at combating corruption appears commendable and a legacy to be emulated by the contemporary Church. The Church cannot close its eyes or pretend not to see corrupt practices. It is the responsibility of the Church to see and speak against all social vices in the society. The Church cannot be selective on what social vices to speak against and still claim to be the Church of Christ, of which John the Baptist was the forerunner.

It is important to note and appreciate the fact that the Church, in its history, has tried to contribute to the socio-economic, political and religious emancipation of human kind in Africa. In the area of health services, the Church has established several hospitals, leprosarium and the likes. In the field of education, schools have been built by different Churches even to the University level. In the agricultural sector, the Church has institutions to improve the life of the people. The role of the missionaries who provided improved seedlings and fruits (like mango, orange and cashew among others) cannot be forgotten. In the social aspect, the stoppage of the obnoxious killing of twins in Nigeria by Mary Slessor is still fresh in mind. The gifts some Churches share to the poor on the social media is also encouraging.

Yet, all the above does not seem to be all the Church can do. The Church should put in more effort in its bid to reach the unreached and treasury looters through evangelism. Like Bishop Desmond Tutu of South Africa, who won a Nobel Prize for peace, the Church today should also endeavour to win the price for combating corruption in Africa. It will be good if the fight against corruption can start within the Church, by combating its materialistic posture through its prosperity messages and controlling all forms of offerings and illegal tolls collected in the name of the Church and the gospel of Jesus Christ.

The Church should be courageous enough to speak against social vices in the society and to confront leaders in government and their collaborators where necessary, even traditional rulers that err and resist all forms of temptations. The Church needs leaders like Bishop Janani Luwum of Uganda, who had the courage to speak against President Idi Amin but was killed in a major cover up by Idi Amin (McCain, 2005:116). This killing marked the beginning of the end of Idi Amin's evil and bloody regime. Nigerians and Africans in general need moral and ethical re-armament and a spiritual resuscitation which is the responsibility of the Church. Only then can we speak of political and socio-economic emancipation, development and a better society.

\section{CONCLUSION}

We come to the conclusion that the conventional concept of policing corrupt individuals, imprisonment and sentencing to death (as a means which is currently being considered by the Nigeria Federal House of Representative) may not be the ultimate solution to corruption in the society. The article has observed a typology in the political and socio-economic situation of the days of John the Baptist and in the contemporary Africa society and Nigeria in particular. Therefore, the article attempted to present John the Baptist's approach to counteracting corruption in his days and recommends the same approach for the Church and its leaders in contemporary Africa. This may help restore dignity and the lost core African values. The Church should not keep silent, but be swift at attacking corrupt practices both within the Church and in the society. The attitude of Church leaders, romancing with treasury looters, should be to reform rather than rejoice and share in the loot. There should be no 
sacred cows or favouritism in the fight against corruption. Any ruler, Church leader, administration or government that discourages corruption should be encouraged to do more, and anyone who encourages corruption should be condemned. If we must remake Africa, we must remake the minds of the Africans. Corruption is a function of character and moral laxity, and it takes character and moral transformation to solve it. Africans today needs self-discipline and self-control to be able to curb the menace of corruption in the society.

\section{REFERENCES}

1. Achebe, Chinua. The trouble with Nigeria, Fourth Dimension Publishers: Enugu, 1983.

2. Anyanwu, H.O. and Manasseh E.Udo. (eds). Religion and Culture: Understanding the Dynamism of Faith in Africa. Beijing P.R, China: Universal Academic Services, 2010. Print.

3. Bruce, F.F. "The General Letters" in Bruce F.F., New International Bible Commentary, Michigan: Zondervan Publishing House, 1979.

4. Brunner, Fredrick Dale, Matthew: A Commentary, Vol. 1, Word Publishing: London, 1987.

5. Drane, John. Introducing the Bible Second Edition, Fortress Press: Minneapolis, 2012.

6. Draper, J.A. "Go sell all that you have..." (Mark 10: 17-30), Journal of Theology for South Africa 79, 1992: 51-73.

7. Friesen, Steven J. "Injustice or God's will? Early Christian Explanations of Poverty". In: Susan R. Holman, Wealth and Poverty in Early Church and Society, Michigan: Baker Publishing Group, 2008.

8. Ige, Abiodun Simoen. "Implication of the culture of Pooling Resources: Illustration from Africa and Acts 4:34-37”. Nigeria Journal of Indigenous Knowledge and Development. September, 2009: 103-111.

9. Igwe, Stanley C. How Africa Underdeveloped Africa, Professional Printers \& Publishers: Port Harcourt Nigeria, 2010

10. Laurence E. Porter, 'Luke', In: Bruce F.F., New International Bible Commentary, based on the NIV, Michigan: Zondervan Publishing House, 1979: 1182 - 1228.

11. Mbiti, John .S. African Religions and Philosophy. New York: Doubleday and Company, Inc.,1970. Print.

12. McCain, Danny. Notes on New Testament Introduction, Nigeria African Christian Textbooks (Acts): Jos, 1996.

13. McCain, Danny. Tough Tests for Top Leaders, Reconnext books: Jos, 2005.

14. Roetzel, Calvin J. The World that shaped the New Testament, John Knox Press: Atlanta, 1985.

15. Stambaugh, John \& Balch, David. The Social World of the First Christians, SPCK: London, 1986.

16. Sunday Tribune 26, Sept. 1993: "Oil Smuggling: Government officials indicted (pp. 1\& 4).

17. Sunday Tribune 24, January 2016: "Reps may consider hanging, amputation for treasury looters (pp.1\&5).

18. The Urantia Book, Paper 135: John the Baptist; http://www.urantia.org/urantia-book-standardized/paper135-john-baptist, Assessed 10.2.2016

\section{PRISTUP KOPRUPCIJI U UČENJU JOVANA KRSTITELJA: REŠENJE ZA CRKVU U AFRICI}

U ovom radu autor razmatra problem korupcije u Africi i način na koji se ova pošast može preduprediti $i$ obuzdati. Analiza je zasnovana na biblijskoj priči o Jovanu Krstitelj koji se beskompromisno borio protiv korupcije. Autor ističe da izvorna afrička kultura tipično neguje vrednosti kao što su poštenje, ljubav prema bliženjem, duh zajednice i druge moralne vrednosti koje se uveliko razlikuju od onih koje postoje danas (individualizam, sebičluk, prevara, korupcija, gomilanje nepošteno stečenog bogatstva). Podaci o visokoj stopi korupcije u Nigeriji i u Africi uopšte potvrđuje činjenicu da je korupcija danas postala skoro deo afričke kulture. Cilj ovog rada je da pažljivo istraži pretnju korupcije u Africi i da predloži učenje i pristup Jovana Krstitelja kao rešenje koje može poslužiti Crkvi u Africi u cilju suzbijanja razornog dejstva korupcije u Nigeriji i na afričkom kontinentu.

Ključne reči: Afrika, korupcija, Crkva, društveni razvoj, Nigerija, vrednosti. 